ISSN 2080-5993

e-ISSN 2449-9811

\title{
Vira Hirnyak
}

University of Banking in Lviv

e-mail:virynya@ukr.net

\section{THE COMPARATIVE EVALUATION \\ OF THE EFFECTIVENESS OF FOREIGN CAPITAL IN THE CAPITAL OF BANKS IN UKRAINE}

\section{OCENA PORÓWNAWCZA EFEKTYWNOŚCI UDZIAŁU KAPITAEU ZAGRANICZNEGO W KAPITALE SEKTORA BANKOWEGO NA UKRAINIE}

DOI: $10.15611 /$ nof.2017.2.02

JEL: G21, G32, G34, L1

Summary: Characteristic features of the manifestation of globalization and international integration in financial relations is the creation of international financial institutions, the entry of foreign capital into the national financial markets and strengthening its influence on the development of national financial systems. In Ukraine, the result of globalization and the international financial integration was the entry of foreign banks into the domestic financial markets by buying absorption of Ukrainian banks establishment by new banks with foreign capital. Among the main advantages of globalization environment is the liberalization of financial markets, the opening of national borders to the international movement of funds in global financial integration space and so on. Along with this in the context of globalization and openness of the national economy in a short period of time has been an increase of foreign capital in the capital of banks in Ukraine, which requires an assessment of the efficiency of capital in the total capital of the bank system and the new trends of the national banking system, introduced by the presence of foreign capital. On the basis of analysis of the indicators the assessment of the effectiveness of foreign capital in the capital of domestic banks was analyzed and positive and negative trends in their participation in the banking system of Ukraine were found. The main goal is comparative evaluation of the effectiveness of foreign capital in the capital of banks in Ukraine and the object are foreign banks in Ukraine. The main methods that are used in this article are statistics and calculations.

Keywords: foreign capital, banking system, the European Union, efficiency, return on equity, return on assets.

Streszczenie: Cechy charakterystyczne przejawu globalizacji i międzynarodowej integracji w stosunkach finansowych to tworzenie międzynarodowych instytucji finansowych, wejście kapitału zagranicznego na krajowe rynki finansowe oraz wzmocnienie jego wpływu na rozwój krajowych systemów finansowych. Na Ukrainie wynikiem globalizacji i międzynarodowej integracji finansowej było wejście banków zagranicznych na krajowe rynki finansowe. Nastąpiło to poprzez zakup i wchłonięcie banków ukraińskich i utworzenie w ich miejsce nowych 
banków z udziałem kapitału zagranicznego. Wśród głównych zalet zjawiska globalizacji jest liberalizacja rynków finansowych, otwarcie granic państwowych na kapitał międzynarodowy i jego przepływ w globalnej przestrzeni finansowej. W efekcie otwarcia rynków krajowych w krótkim okresie nastąpił wzrost udziału kapitału zagranicznego w kapitale banków ukraińskich. Wymaga to oceny efektywności udziału kapitału zagranicznego w całkowitym kapitale bankowym oraz analizy nowych trendów w krajowym sektorze bankowym, wprowadzonych przez obecność kapitału zagranicznego. Na podstawie analizy wskaźników dokonano analizy skuteczności udziału kapitału zagranicznego w kapitale krajowego sektora bankowego oraz poddano badaniu pozytywne i negatywne trendy w tych zmianach. Głównym celem artykułu jest porównawcza ocena skuteczności kapitału zagranicznego w kapitale banków na Ukrainie, a przedmiotem badania są banki zagraniczne na Ukrainie. Główną metodą zastosowaną w przeprowadzonym badaniu jest analiza ilościowa danych statystycznych.

Słowa kluczowe: kapitał zagraniczny, system bankowy, Unia Europejska, efektywność, zwrot z kapitału własnego, zwrot z aktywów.

\section{Introduction}

Characteristic features of the manifestation of globalization and international integration in financial relations consist in the creation of international financial institutions, the entry of foreign capital in national financial markets and strengthening its influence on the development of national financial systems. In Ukraine, the result of globalization and the international financial integration was the entry of foreign banks into the domestic financial markets by buying absorption of the Ukrainian banks, new banks with a foreign capital. Among the main advantages of globalization environment is the liberalization of financial markets, the opening of national borders to the international movement of funds, integration into the international financial and others. Along with this in the context of globalization and openness of the national economy in a short period there has been devaluation of the national currency in Ukraine, numerous (above 60) bankruptcies of Ukrainian banks and uncertainty in the public safety of domestic banks in the last years which have led not only to an outflow of deposits from the system, but also to the redistribution of deposits into the banking system for financial institutions with European owners.

Studies evaluating the effectiveness of banks foreign capital and their impact on the banking system of Ukraine and other countries engaged both domestic and foreign authors, in particular: A. Abalkina, B. Ahabalyan O. Alekseeva, A. Butenko, A. Vernikov, O. Drugova, O. Dzyublyuk, M. Kozoriz, V. Mishchenko, A. Omelchenko, E. Osadchy, T. Smovzhenko, A. Prymostka and others.

At the same, nowadays the increasing international integration and worsening financial crisis in Ukraine raise the question of the lack of financial resources, which can cause a number of problems, namely destabilization in the monetary sphere, reducing the competitiveness of Ukrainian banks with the simultaneous increase of foreign capital. 
The purpose of this article is to evaluate the effectiveness of foreign capital in the capital of banking institutions of Ukraine.

\section{Analysis of the number of foreign banks in Ukraine in the period 2008-2016}

There are a lot of works published abroad which are devoted to the comparative effectiveness evidence of foreign and local banks using econometric methods of relationship between bank ownership and the efficiency and profitability of its work. It is usually argued that state ownership of banks is the least effective of all, and private/foreign banks are more efficient than private/national national ones. The main arguments for this assertion is that modern banking technologies and accumulated human capital of the parent bank used "daughters" [Worldbank 2012] .

J.P. Bonin and his colleagues have attempted a comprehensive study to test the effectiveness of comparison of foreign and local banks. The sample included 856 observations for the period 1996-2000. 225 banks of eleven countries of Central and Eastern Europe (CEE) followed the main results. In Central and Eastern Europe alone private property - does not guarantee the efficiency of banks, and there is no statistical evidence that state ownership is less efficient than national private one. However, banks controlled by a foreign strategic investor, collected more private contributions and issue more loans than local private and state banks of the same size. The increase of the efficiency of the transfer of control over the bank into the hands of foreign investors amounted to at least $6 \%$, and the equity of the bank's international institutional investors (such as EBRD) - 9\%. It should, however, be mentioned that foreign property ownership, especially in the EBRD, could be initially more successful for banks - not least because they underwent the specific procedure of preliminary check [Bonin et al. 2004].

In his study of the material of Central and Eastern Europe A. Vernikov shows that banks belonging to foreigners in the region are growing at the same rate as the privatized or created foundations of local private banks. Those, in most CEE countries, including Ukraine, are market leaders in small business lending by foreign banks (consumer finance - local banks). In most developed countries the situation is different: foreign banks locally yield efficiency, which is particularly well illustrated by the USA and Germany. In foreign banks usually there is much more expensive passive basis as there is access to the small depositors, which serve as a cheap source of funding and is usually complicated force loyalty past their banks [Vernikov 2006, pp. 63-71].

The extent of participation of banks with foreign capital in the banking systems of different countries is measured using the metrics, including:

- number of operating banks with foreign participation,

- their share in total capital and in assets of banking system,

- banking performance (return on equity and return on assets). 
1. Banks with partial participation of foreign capital, which authorized funds are derived from a domestic and foreign capital.

2. In banks with $100 \%$ foreign capital (commercial banks), statutory funds are formed only by foreign capital [Law of Ukraine 2009, pp. 4-40].

In 2016 National Bank of Ukraine defined a division separation of commercial banks into groups:

- banks with the state share (in which the state owns over 75\%);

- banks forming foreign banking groups (banks, controlling shareholders which are foreign banks);

- Group I (banks, the share of assets which is more than $0.5 \%$ of banking system assets);

- Group II (banks, the share of assets is less than $0.5 \%$ of banking system assets) [National Bank of Ukraine 2015].

According to the National Bank of Ukraine as of April 1, 2016 there were 111 banks, including 43 with foreign capital (on $1 / 1 / 16-41$, on $1 / 1 / 15-51$ ), with $100 \%$ foreign capital - 17 (on 01/01/16 - 17, on 1/1/15 - 19). The share of foreign capital in the authorized capital of Ukrainian banks was $48.8 \%$ (on $01 / 01 / 16-43.3 \%$ on $01 / 01 / 15-32.5 \%$ ). According to statistics for the last year the number of banks with foreign capital decreased significantly. However, there is a dynamic increase in the share of foreign capital in Ukrainian banks, so the increase in financial risks related to this process should be taken into account.

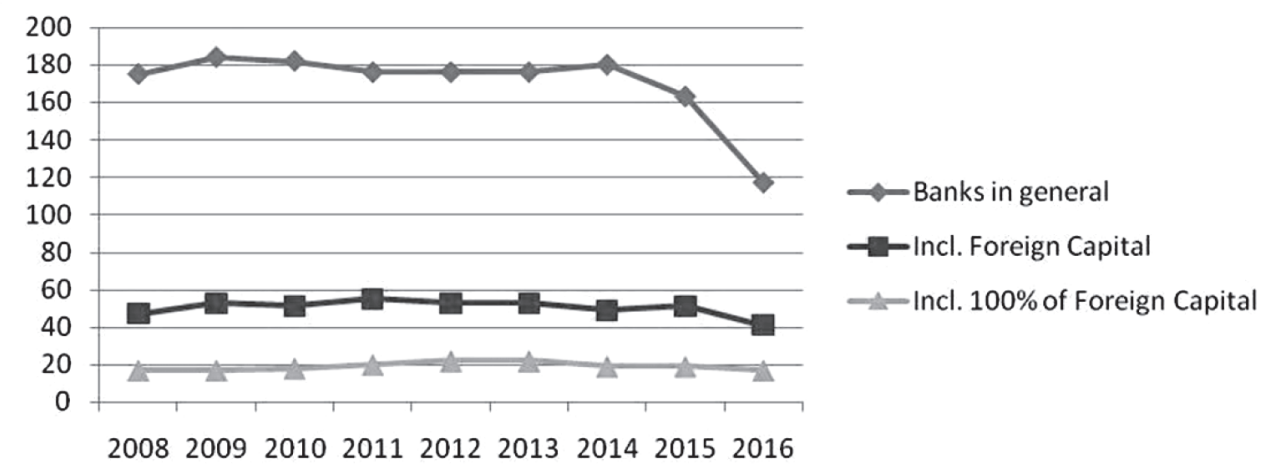

Figure 1. Changes and trends in the proportion of foreign bank branches to commercial domestic banks Source: own work based on [National Bank of Ukraine 2016].

According to the classification of banks with foreign capital, a group of banks under full control of foreign capital include: Prominvestbank, Raiffeisen Bank Aval, Sberbank, Ukrsotsbank, UkrSibbank, VTB, Credit Agricole, OTP, Citibank, ING Bank Ukraine, Pravex-Bank, Vies Bank, BM Bank, Pireus Bank, Marfin Bank, Credit Europe, Deutsche Bank DBU, SEB CORPORATE. Multinational banks that 
enter the markets of other countries banking services have well equipped capital of their parent companies. An important element of the strategy of their behavior abroad is not just the fulfillment of all legal requirements of capital but the steady growth of capital generally shown in Figure 2. Thus, the amount of capital banks with foreign capital on 01.01 .2016 was 32,574,829 thousand UAH. The achieved level of capitalization of banks with foreign participation let them increase their capital in the total capital of the banking system, which is $43.3 \%$ of the whole population. With a further increase of capital by foreign banks, they can be considered as the backbone which activities in a decisive way affect the fate of the capital of the banking system of Ukraine.

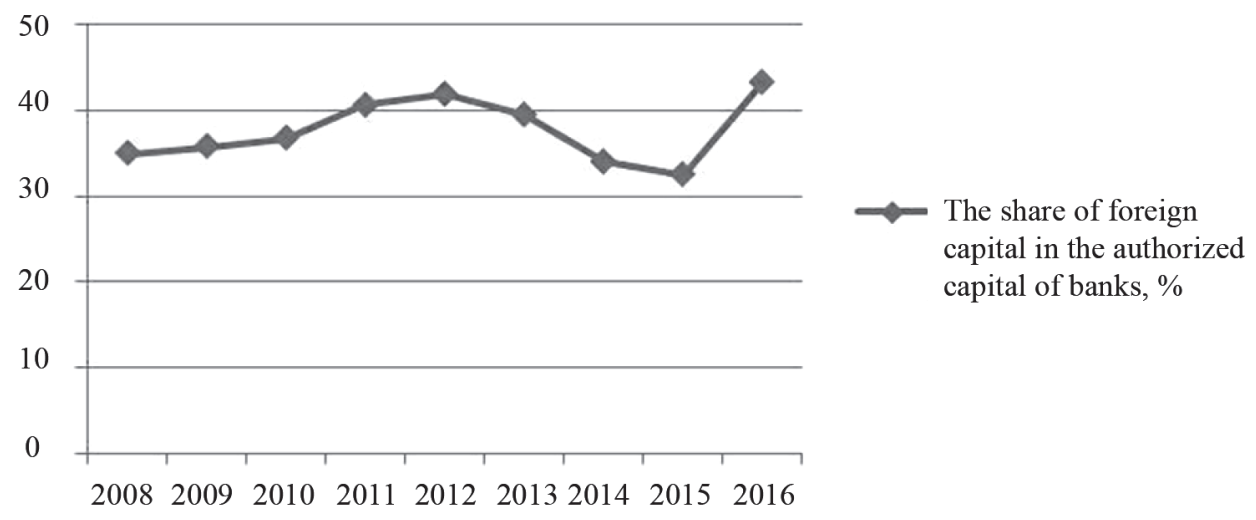

Figure 2. The dynamics of capital of banks with foreign capital at the beginning of the period Source: own work based on [National Bank of Ukraine 2016].

By 2016, there was a group of four bank groups (Table 1).

Table 1. Group of Ukrainian banks on 01.01.2013

\begin{tabular}{|l|c|c|c|c|}
\hline $\begin{array}{c}\text { Groups of banks } \\
\text { by assets }\end{array}$ & $\begin{array}{c}\text { Total number } \\
\text { of banks } \\
\text { in the group }\end{array}$ & $\begin{array}{c}\text { Number of banks } \\
\text { with foreign capital } \\
\text { in the group }\end{array}$ & $\begin{array}{c}\text { Share } \\
\text { Eroup of the banks } \\
\text { (UAH) }\end{array}$ & $\begin{array}{c}\text { of foreign } \\
\text { capital in total } \\
\text { capital } \\
\text { groups, } \%\end{array}$ \\
\hline The largest banks & 18 & 11 & 83904482 & 36.22 \\
\hline Larger banks & 19 & 13 & 16980481 & 66.89 \\
\hline Medium banks & 11 & 11 & 9951867 & 51.28 \\
\hline Small banks & 176 & 17 & 16325474 & 19.17 \\
\hline In general & 52 & 127162304 & 39.31 \\
\hline
\end{tabular}

Source: own work based on [National Bank of Ukraine 2008-2016]. 
Analyzing the share of foreign capital in total capital group it was notocied that the largest concentration of foreign capital is in the second group group of major banks $-66.89 \%$ but the amount of equity in group two is less than in the first group by about 5 times. It can also be seen the group of small banks in the amount of equity capital exceeds the equity in the group of medium-sized banks by 1.7 times, and the share of foreign capital in groups after less. This shows an uneven distribution of foreign capital in total capital groups. This is because foreign banks when entering the banking sectors of other countries are guided by different motives. Thus, banks are the first and the second group in terms of assets, with the goal of expansion into new banking services markets. Using new technology and efficient methods of banking, the banks easily attract the best customers and capture the most profitable market segments. In this case, foreign investors once choose to buy the largest domestic banks, or direct the activities of the acquired banks to expand lending operations and increase their presence.

\section{Risks and profitability of foreign banks in Ukraine}

All this creates conditions for the development of new banking services to foreign banks, which requires the measurement of risk of foreign capital in the domestic banking market.

The activities of any bank are inevitably accompanied by a variety of internal and external risks. We estimate the size of the overall bank risk for banks with Ukrainian capital and the participation of foreign capital. The level of total bank risk is calculated as:

$$
L=\frac{A}{C a},
$$

where: $L$ - total bank risk; $A$ - the bank's assets; $C a$ - the amount of equity.

Given the conventional approaches risk assessment is based on the following criteria:

$L-0$ to $5-$ low risk,

$L-$ from 5.1 to 10 - average risk,

$L-10$ and above - critical level of risk [Igosheva 2011].

According to the financial statements of banks, Ukraine expected total amount of risk for banks and the results are presented in Table 2.

Based on Table 1, banks with average risk include Ukreximbank and Oschadbank - banks owned by the state. Higher risk refers to the remaining banks with Ukrainian capital and foreign capital. Significant impact on the activities of foreign banks can be seen through internal factors, and the critical level of risk is described by high amount of overall risk of banks with foreign capital. This demonstrates the need to reduce the risk of banks in Ukraine. 
Table 2. The size of overall risk for banks in Ukraine in 2016

\begin{tabular}{|c|c|c|c|c|c|c|}
\hline \multirow[b]{2}{*}{ Indicator } & \multicolumn{5}{|c|}{ Ukrainian banks } & \multirow{2}{*}{$\begin{array}{l}\text { Average } \\
\text { level of } \\
\text { risk, } \%\end{array}$} \\
\hline & $\begin{array}{c}\text { «Bank } \\
\text { Pivdennuy» } \\
\text { (Ukraine) }\end{array}$ & $\begin{array}{c}\text { Ukreximbak } \\
\text { (Ukraine) }\end{array}$ & $\begin{array}{c}\text { Oshchadbak } \\
\text { (Ukraine) }\end{array}$ & $\begin{array}{c}\text { «Diamondbank» } \\
\text { (Ukraine) }\end{array}$ & $\begin{array}{c}\text { Rodo- } \\
\text { vidbank } \\
\text { (Ukraine) }\end{array}$ & \\
\hline $\begin{array}{l}\text { The total } \\
\text { coefficient } \\
\text { risk } \\
\text { of banks }\end{array}$ & 18.1 & 6.5 & 5.2 & 28.9 & 13.7 & 14.5 \\
\hline \multirow[t]{2}{*}{ Indicator } & \multicolumn{5}{|c|}{ Foreign banks } & Average \\
\hline & $\begin{array}{c}\text { Raiffeisen } \\
\text { Bank } \\
\text { Aval (Austria) }\end{array}$ & $\begin{array}{c}\text { Ukrsibbank } \\
\text { BNP Paribas } \\
\text { Croup } \\
\text { (France) }\end{array}$ & $\begin{array}{c}\text { Sberbank } \\
\text { (Russia) }\end{array}$ & $\begin{array}{l}\text { Ideabank } \\
\text { (Poland) }\end{array}$ & $\begin{array}{l}\text { Credit } \\
\text { Agricol } \\
\text { Bank } \\
\text { (France) }\end{array}$ & $\begin{array}{l}\text { level of } \\
\text { risk, \% }\end{array}$ \\
\hline $\begin{array}{l}\text { The total } \\
\text { coefficient } \\
\text { risk } \\
\text { of banks }\end{array}$ & 17.5 & 21.5 & 15.8 & 14.3 & 12.5 & 16.3 \\
\hline
\end{tabular}

Source: own work based on [National Bank of Ukraine 2008-2016].

Russian banks were in the bottom half of the ranking table due to lower ratings of the country of origin of capital, the worst quality loan portfolio and lower availability of highly liquid assets compared with foreign competitors. Somewhat better places went to Russia Sberbank and VTB due to greater systemic importance, the combination of the average yield with low volatility shares during the 5-year horizon and positive financial results.

Loss of control over the banking system from domestic investors could change the movement of financial flows in the country with a direct support of national and strategic importance to the economy businesses and manufacturers to finance enterprises with foreign capital and more favorable cost to foreign investors.

The level of risk for the economy, where the share of foreign capital in the banking system and the level of benefits from the gradual implementation of this process will depend primarily on the clear position of the country's allowable level of foreign capital in the banking system, are quality objectives infusion origin and adopted policies to protect national interests. The risk of the presence of foreign capital in the banking system is associated with the uncertainty of the effects of the foreign level of capital of the banking system and the economy of the country of origin of foreign capital.

Leading places in the ranking table are taken by multinational banks to provide the optimum combination of low-risk source of capital, the stable dynamics of the shares of parent groups with high profitability, liquidity and asset quality. On the top of five rankings in retail are only two French banks, while the Germans, Swedes 


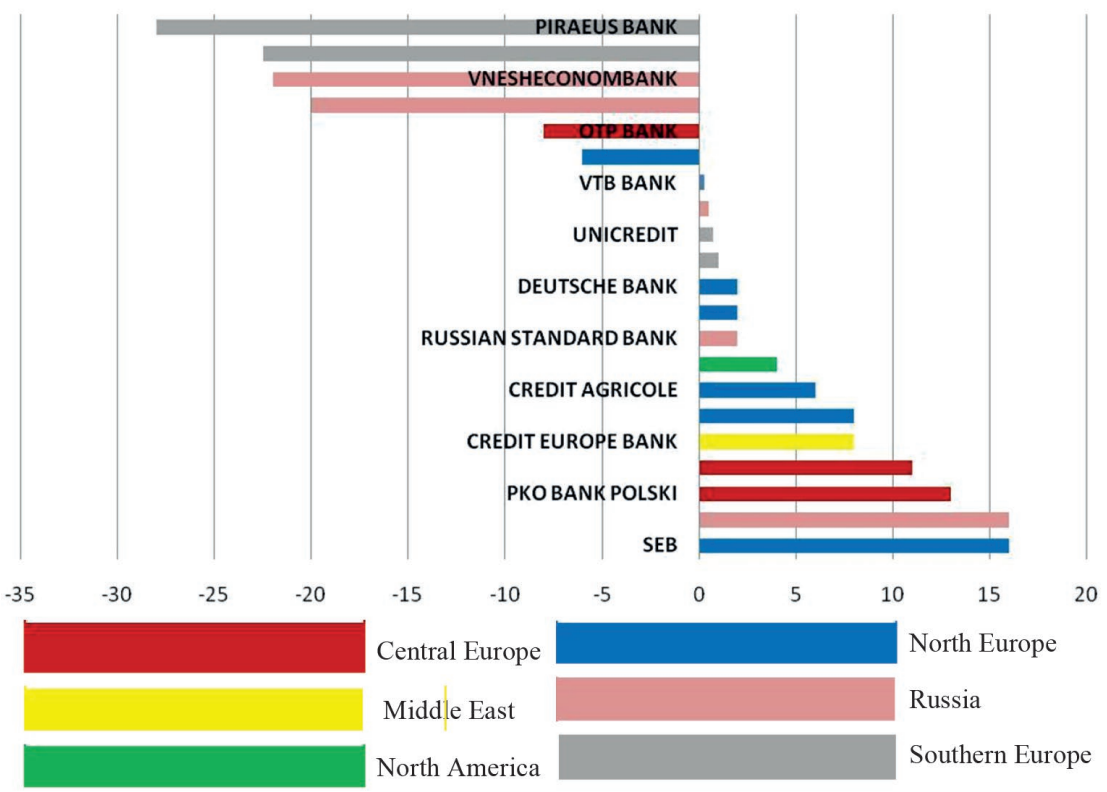

Figure 3. Profitability of equity of foreign banks in 2015 , \%

Source: own work based on [National Bank of Ukraine 2015].

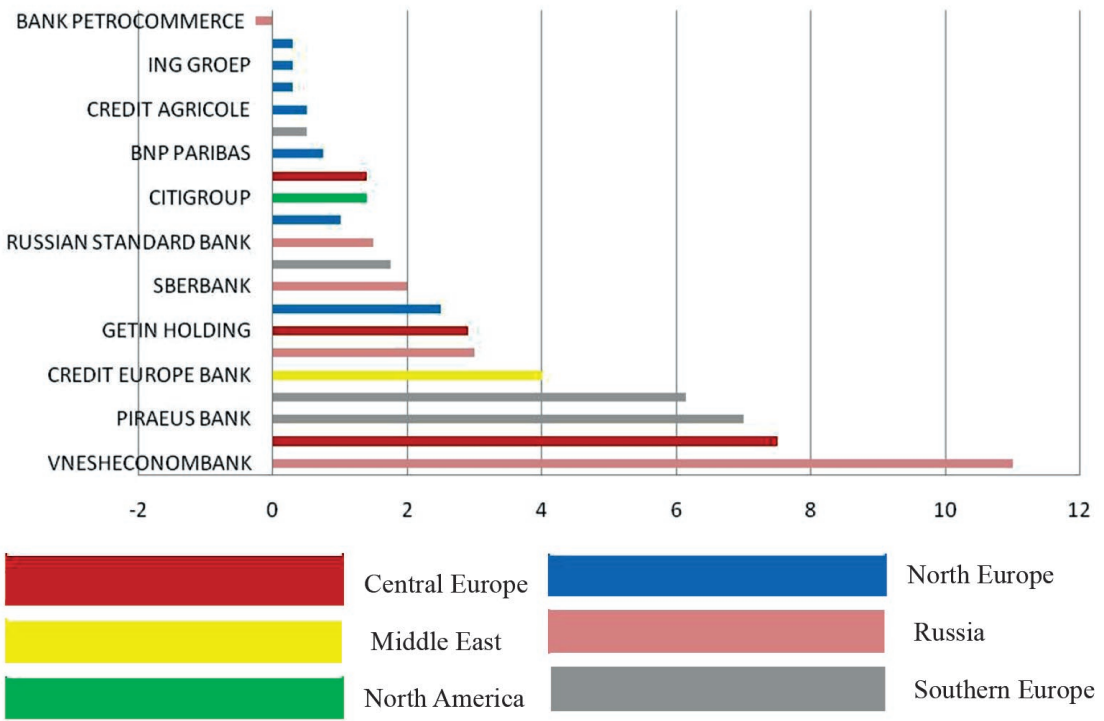

Figure 4. The ratio of allocations to provisions for impairment of loans to the loan portfolio, $\%$ Source: own work based on [National Bank of Ukraine 2015]. 
and Americans conduct their activities in the investment and corporate banking. Deutsche Bank and Citibank began activities in Ukraine as specialized banks for legal entities.

Currently, foreign capital in Ukraine is represented by 23 countries. The largest share in the total capital belongs to Cyprus (20.3\%), Austria (20.3\%), France (12.3\%), Russia (9.7\%), the Netherlands (8.2\%), Poland (7 9\%), Sweden (6.1\%) (Figure 5) [National Bank of Ukraine 2015].

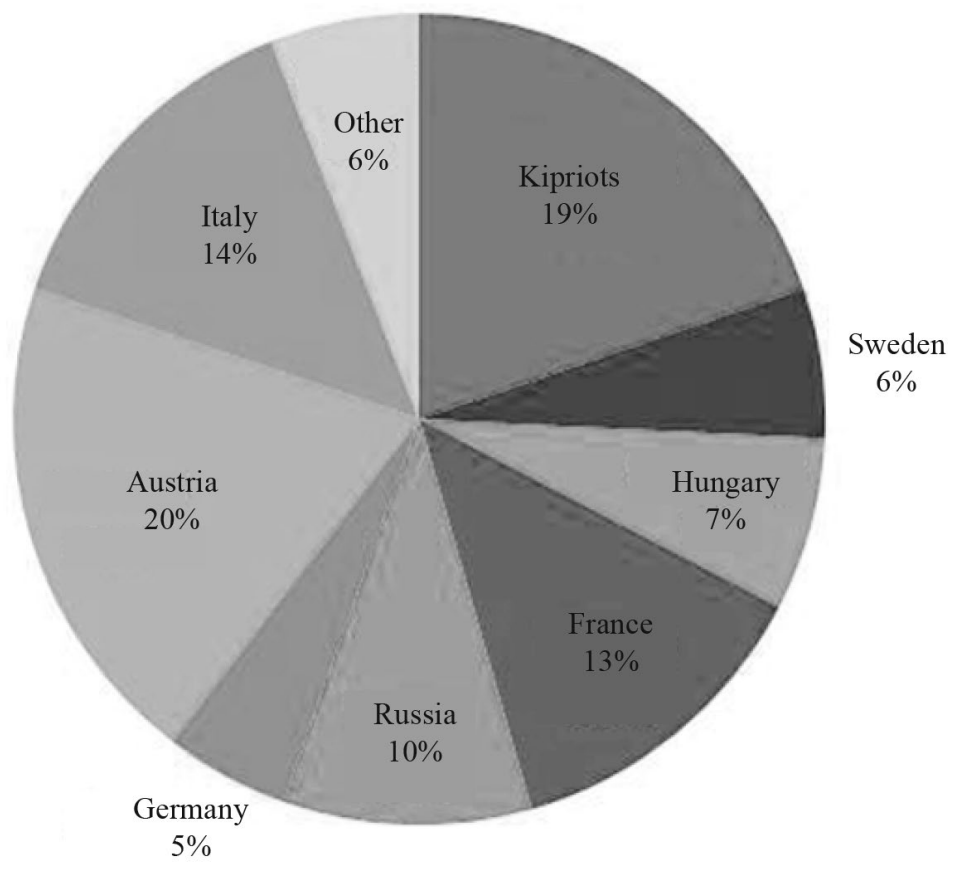

Figure 5. Distribution of banking assets controlled by non-residents in Ukraine in 2016

Source: own work based on [National Bank of Ukraine 2015].

The growing market place lacked everything, but usually in times of crisis there is a process of redistribution of property. The question is which of the investors most interested in Ukrainian banks is able to increase its market share and what are the consequences for it for economy of Ukraine.

\section{Return on average assets and equity (ROA, ROE)}

Let us calculate the return on equity (ROE) and return on assets (ROA) of the banks foreign capital that operate in Ukraine, and return of Ukraine's banking system as a whole (Table 3). 
In the world practice, these figures are the main performance indicators of banking. In particular, the return on equity characterizes the economic return of capital and capital efficiency and shows the amount of net profit per 1 USD capital bank. It is believed that at bank works effectively when ROE indicator is not less than $15 \%$. Rentabelnist assets reflect the bank's internal policies effective asset and liability management activities and bank managers to optimize assets and liabilities in terms of income and expenditure of the bank. Optimal values of ROA, at which it is recognized that the bank has leverage available resources, should be at least $1 \%$.

Table 3. Return on average assets and equity ROA, ROE

\begin{tabular}{|c|c|c|c|c|c|c|c|c|c|c|}
\hline \multirow{2}{*}{ Indicator } & \multicolumn{2}{|c|}{01.01 .2007} & \multicolumn{2}{|c|}{01.01 .2008} & \multicolumn{2}{|c|}{01.01 .2009} & \multicolumn{2}{|c|}{01.01 .2010} & \multicolumn{2}{|c|}{ 01.01.2011 } \\
\hline & ROE & ROA & ROE & ROA & ROE & ROA & ROE & ROA & ROE & ROA \\
\hline $\begin{array}{l}\text { Foreign } \\
\text { banks }\end{array}$ & 10.6 & 1.17 & 7.95 & 0.82 & 6.02 & 0.66 & -32.57 & -3.48 & -18.34 & -2.28 \\
\hline 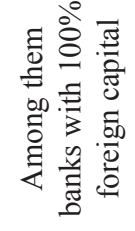 & 16.79 & 2.02 & 10.7 & 1.23 & 6.63 & 0.73 & -5.56 & -0.75 & -2.71 & -0.39 \\
\hline 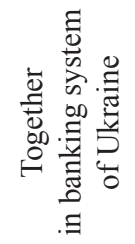 & 13.52 & 1.61 & 12.67 & 1.5 & 8.51 & 1.03 & -32.52 & -4.38 & -9.46 & -1.38 \\
\hline
\end{tabular}

Source: own work based on [National Bank of Ukraine 2007-2011].

The data in Table 3 indicate a decrease in the efficiency of banks in Ukraine with foreign capital. In particular, decrease in return on equity, and reduction of the return on assets of foreign banks operating in Ukraine are observed. Size of ROE and ROA indicators is below the optimal values. Thus banks with $100 \%$ foreign capital show a slightly better position than banks with foreign capital in general. Value return on assets in the whole banking system amounted to more than $1 \%$ in the period 20062008, describing the work of an effective asset and liability management of banks. At the same time, banks with foreign capital showed the importance of ROA $1.17 \%$ (which is greater than 1\%) only at the beginning of 2007. In the next period due to the decrease in profitability of active operations of banks it declined and at the beginning of 2010 reached a negative value, and the index ROA for banks foreign capital amounted to -3.48 and -0.75 for banks with $100 \%$ participation of foreign investors. This situation is observed throughout 2010 and as on 01.01.2011. ROA for the indicator banks with foreign capital amounted to -2.28 , and for banks with 
$100 \%$ participation of non-residents to 0.39 and in general banking return on assets also showed a negative value and amounted to -4.38 on 01.01 .2010 . and -1.38 on 01.01.2011. Profitability met optimal capital level only for banks with $100 \%$ foreign capital at the beginning of 2007 and amounted to $16.79 \%$. Value return on capital demonstrated a negative trend to decrease in both groups of banks with foreign capital (including 100\% foreign capital), and the whole banking system in Ukraine, which led to a negative value of the indicator at the beginning of 2010 and 2011 in particular. In the whole system banks return on equity was -32.52 on 01.01 .2010 and -9.46 on 01.01 .2011 , for banks with foreign capital it was -32.57 on 01.01 .2010 and -18.34 on 01.01 .2011 , and for banks with $100 \%$ foreign capital -5.56 on 01.01 .2010 and -2.71 on 01.01.2011. This suggests the inefficient use of capital of banking institutions that operate in Ukraine [National Bank of Ukraine 2016].

\section{Conclusions}

Our calculations showed that the concentration of comparative evaluation of the effectiveness of foreign capital in Ukrainian banking system witnessed the need to control the movement of cash flows within the country and from the positions outside the public interest. As the impact of globalization on developing current banking system of Ukraine is very important, has direct movement and the trend of the short term continues, we must clearly define the ratio between foreign and domestic bank capital today.

In the management process of entry of foreign capital into the banking system Ukrainian governments should use individual approach, the presence for each foreign bank decisions on the specific areas of its activity according to specific financial figures on the domestic financial market.

In order to create competition with foreign banks an active job of domestic banks is required to improve their balance sheets and quality management as well as to optimize an approach to their costs. In turn, public authorities should aim to further develop the refinancing, fully executing the National Bank as a lender of the last resort. These comprehensive and diverse activities will turn to domestic banks competitors of the global financial infrastructure and increase efficiency of their activities.

The next propositions have to be the main criteria for dividing the risk of foreign capital in the banking system. They are:

- functional level manifestation of the effects of risks,

- segment capture of market banking services,

- strategy penetration of foreign capital into the banking system of Ukraine,

- environment origin of risk,

- stage of penetration of foreign capital into the banking system of Ukraine,

- hierarchical structure influence of the risk on the development of the country. 
The advantages of foreign capital, especially for the banking system of Ukraine are the following:

- filling the domestic currency market resources and reducing dependence on limited domestic currency funds;

- reducing slightly the cost of foreign exchange resources in the conditions of a stable exchange rate and the absence of excessive demand for foreign currency;

- expanding opportunities for efficient allocation of capital and the scale of project financing and foreign direct investment;

- establishing and expanding the relations between national and foreign banks to facilitate the implementation of fast and quality service of its own currency and client interests;

- expanding access to international money markets and capital markets.

The emergence of new foreign investors in the banking sector in the next two years is unlikely, but in the medium term it depends on the outcome of reforming the Ukrainian economy and increase of its investment attractiveness.

In our view, an important step in the development of the domestic banking market should be to stimulate the opening of branches of foreign banks in certain cities and special economic zones, on the one hand and to promote the development of the banking market in all regions, on the other. It will allow domestic banks to compete and cooperate with foreign partners.

\section{References}

Bonin J.P., Hasan I., Wachtel P., 2004, Bank performance, efficiency, and ownership in transition countries, BOFIT Discussion Paper, no. 7, pp. 45-60.

Igosheva O., 2011, Foreign investments in banking system of Ukraine and their mechanism, http:// www.economy.nayka.com.ua/?op $=1 \& z=2058$.

Law of Ukraine, 2009, Banks and baking activities. Law and normative acts from banking activities no. 2, pp. 4-40.

National Bank of Ukraine, 2015, Commission supervision and regulation of banks decisions, 31 December, no. 657, on the distribution of banks in the group, http:/www.bank.gov.ua/control/uk/ publish/article?art_id=25852020.

National Bank of Ukraine, 2016, Statistic materials, http://www.bank.gov.ua/control/uk/index (access 15.09.2016).

Vernikov A., 2006, The share of foreign capital in the banking sector: issues and methodology, pp. 63-71, http://www.cbr.ru/publ/MoneyAndCredit/vernikov.pdf.

Worldbank, 2012, Comparative effectiveness evidence of foreign and local banks, http://www.worldbank.org/. 